\title{
19. Reinventing Australian Conservatism in the States: New Leadership and the Liberal Revival under Bolte and Askin
}

\author{
Norman Abjorensen
}

\section{Introduction}

The formation of the Liberal Party of Australia in the mid-1940s heralded a new effort to harness the forces of liberalism and conservatism in opposition to Labor Party rule in the latter years of World War II and immediately after. It was not until 1949 that the party gained office at Federal level, beginning what was to be a record unbroken term of 23 years, but its efforts faltered at state level in Victoria, where the party was divided, and in New South Wales, where Labor was seemingly entrenched. The fortunes were reversed with the rise to leadership of men who bore a different stamp to their predecessors, and were in many ways atypical Liberals: Henry Bolte in Victoria and Robin Askin in New South Wales. Their leadership is examined here in the broader context of the post-war liberal revival as well as the ways in which the new Liberal Party sought to engage with and appeal to a wider range of voters than had traditionally been attracted to the non-Labor parties. Above all, this chapter argues that Australian conservatism was revitalised through a concerted effort to promote leaders more readily identified with ordinary Australians than had been the case pre-war. It was the colloquialisation of non-Labor politics.

Political history in Australia, as well as political journalism, has come to mean, almost invariably, a focus on the Commonwealth as the locus of power and the exclusive subject of political interest. This one-dimensional approach to both scholarship and journalism has been correctly characterised as 'doomed to incompleteness and distortion' by its neglect of the two-dimensional system that exists in Australian political life (Galligan 1986: x). To overlook the state dimension is to miss a key dynamic in political life, particularly in regard to parties. The rise of the Liberal Party to its post-war ascendancy was far more than the achievements of Robert Menzies on the national stage.

\section{Conservative politics in crisis}

World War II had left its stamp indelibly on the Australian nation; no part of it was left untouched by the experience of mobilisation and the fear of invasion. The characteristics of service life permeated civilian life after the war and the 
advent of the Cold War, coupled with the considerable tensions generated by the fears surrounding communism at home and ongoing uncertainty in the international situation, ensured that ideas about defence and national security remained prominent in the public mind. Australia's official war historian Paul Hasluck attempted to capture the deep emotions that the war experience triggered, noting in a description of marching troops 'the strong and binding comradeship that a shared grief and pride can bring to men and women' and especially the demeanour of 'the men who had fought, strong, sun-tanned, tight-jawed and fit, swung past with that loose and confident stride that only Australian soldiers have' (Hasluck 1970: 625). It was that 'loose and confident stride' that would define the ethos of post-war Australia. It became, even at a subliminal level, a potent symbol of what Hasluck identified as the 'stronger national consciousness' (Hasluck 1970: 627) that emerged after the war. It would find in its own way an expression in political culture that defined both a character type and a set of attitudes.

As World War II drew to a close in 1945, conservative politics in Australia was in disarray. In the bitter and lingering aftermath of the Great Depression and in the uncertain handling of the war effort in the first Menzies Government (1939-41), the conservative forces were in serious decline and were seen to be increasingly irrelevant, venting what feeble energies they retained on internecine conflict. The resurrection of the 79-year-old Billy Hughes as leader of the United Australia Party (UAP) after the resignation of Robert Menzies was a striking symbol of the lack of vitality in the ramshackle UAP and its cause. Its conservative coalition partner, the Country Party, was also in conflict, having split in 1939 over its relations with the UAP. Later the Country Party saw one of its members cross the floor with an independent to bring down the government, briefly led by Country Party Leader Arthur Fadden in 1941. Furthermore, the Country Party firmly rebuffed invitations to attend the gathering of conservative and liberal organisations in Albury and Canberra in 1944 from which the modern day Liberal Party emerged after the disintegration of the UAP.

In Victoria, the party had been effectively sidelined since 1935 by an alliance between the Country Party and Labor, and this had led to a damaging split and further electoral decline in 1945. In New South Wales the UAP-Country Party government slid quietly into oblivion in 1941 as the ALP shrugged off the influence of J. T. Lang and, under a new and appealing leader in William McKell, surged back into office in what was to be the beginning of a record 24-year term. In terms of the all-important public perception, the UAP had ceased to be 'dinkum'. It was no longer seen as representing popular aspirations; it was perceived as a self-serving and squabbling oligarchy remote from the problems and issues of everyday Australians and lacking the legitimacy to be considered a viable alternative to Labor as the party of government. 
Concerns ran deep. Business was worried that the image of private enterprise continued to be tainted in the public mind after the Depression and that greater government involvement in the economy, under both wartime emergency controls and post-war reconstruction, was not only unopposed but appeared to have wide public support. The Institute of Public Affairs was formed precisely to wage such a battle, although the Melbourne and Sydney branches differed in their attitudes to the degree of intervention that was acceptable. Business was also concerned that its interests were not being articulated at the political level. The leading figures behind the formation of the new Liberal Party were keenly aware of the problems the party faced, among them a lack of public credibility, the perception that conservative politicians appeared to be more English than Australian, and that, in the past, conservative politics had failed to reach into the lives of, and appeal to, ordinary Australians. Above all, there had been a failure of leadership.

The general feeling of inadequacy on the non-Labor side, coupled with an air of enveloping crisis, is reflected in the musings of a prominent business figure, F. E. Lampe, ${ }^{1}$ about the results of the 1943 Federal election, which he characterised as: 'United they stood, divided we fell' (Lampe 1943: 1). Lampe noted the care taken by the Labor Party not to reveal to the public any sign of dissension in its ranks and contrasted Prime Minister John Curtin's leadership with the lack of leadership in the UAP. He also noted a number of other problems with the non-Labor parties, among them: disagreement between UAP and Country Party leaders on major points of policy; the lack of clear and constructive policy positions; a tendency towards political expediency and lack of organisation; and the 'possibility that the Labor Party is regarded as more Australian than the UAP [and] that the UAP is regarded as being more susceptible to English than to Australian influences'. He identified a widespread belief that Labor offered the best hope of post-war social security and avoidance of depression.

Lampe was concerned that while Labor was focusing on post-war reconstruction, the two non-Labor parties during the 1943 campaign had merely spoken 'more or less vaguely about the need to preserve private enterprise'. They had 'completely failed' to enunciate a policy that would be capable of avoiding depressions and other social evils that followed the 1914-18 war (Lampe 1943: 3). Even the august Sydney Morning Herald, generally a supporter on the non-Labor side, was strongly critical of the malaise which had overtaken the emphasise parties, accusing them of representing 'vested interests' which, while not represented directly, were nevertheless organised 'through a clique of professional politicians who close their ranks to new talent' (Sydney Morning Herald 1943a).

The UAP was being seen increasingly as irrelevant, both to the demands of the business community and to the so-called 'middle ground' which it needed if it 
was to achieve electoral success (Lonie 1978: 69). Its ability to match Labor, ideologically or politically, was constantly to be found wanting. The prominent businessman and later Federal President of the Liberal Party, T. M. Ritchie ${ }^{2}$ echoed the sentiments of many when he said: 'It is obvious that the weakness of our opposition to the promotion of socialistic political thought and effort arises largely out of our failure to achieve a continuity of political effort by those citizens who do not share the socialistic viewpoints' (Speech to Darlinghurst branch 1945).

There were two recurring themes in the Sydney Morning Herald's ongoing critique of the non-Labor malaise - the need to move away from simple anti-socialism and protection of vested interests ('obstructive conservatism') to a broader, more robust liberalism (Sydney Morning Herald 1943b) and greater consideration given to the type of candidate needed. The latter contained a prescient insight into the type of Liberal leaders who would emerge in the immediate post-war years and addressed what the Herald had long identified as a pronounced lack of practical administrative ability in non-Labor ranks. 'Administrative capacity is obviously needed, but unlike political leadership, it is fairly plentiful in this country. The problem is only how to associate it with politics' (Sydney Morning Herald 1943c).

In other words, the pool of talent for leadership was as narrow as it was shallow; the class and social constraints of non-Labor merely churned out more of the same type of politician. If a new start were to be made - and this was the thrust of the Herald's argument - then serious attention needed to be given to the encouragement of more diverse talents, an issue that the later influx of ex-servicemen would address and in so doing provide leaders at state level such as Henry Bolte in Victoria and, later, Robin Askin in New South Wales. It was this subtle shift that helped provide the subsequent Liberal Party with the essential ingredient needed to build electoral success on its mass-base organisation - and that was mass appeal.

\section{A sceptical electorate}

While the failure at the Federal election in 1946 and the ructions in Victoria were disheartening to many Liberals, there were those in office in the new party who used the occasion to exhort members to even greater efforts to convince the electorate that they were truly what they claimed to be. In a summing up of the party's defeat in 1946, The Victorian president, W. H. Anderson ${ }^{3}$ suggested that the electorate remained sceptical of the new party.

[A]t the last Federal election we nearly won. We had an excellent policy. It was not the policy that lost the Election, and it was not that the people were not getting dissatisfied with the Labor Party. What lost us the election was that the people were not yet satisfied of the bona fides of 
the Liberal Party. They were not satisfied that we were dinkum, that we meant what we said, and that we really stood for the people's party representing all sections throughout the country. If they had believed that we would have been in power to-day. You are the only people that can convince them (Anderson 1947: 3).

A new party it might have been, but the past cast a shadow over the present, especially so as many of the names prominent in the new Liberal Party had been equally prominent in the now widely criticised United Australia Party; the people, it seemed, remained unconvinced. Menzies has recounted how he was reasonably pleased with the modest gains in 1946, but that there were also 'plenty of onlookers' who were exceedingly critical, and that his leadership was once more being brought into question (Menzies 1969: 293). Leadership, it seems, was very much part of the debate and resurfaced as an issue early in 1949 when the Institute of Public Affairs, lamenting Australia's poor productivity, especially when compared with the Americans, called for a 'new national outlook and faith'. Leadership was found to be lacking 'at the highest order of political and industrial statesmanship', and what was needed were 'leaders who can bring the nation to a new way of life' ('Triumph or Disaster?' 1949: 13-4).

Sincerity had not been proven, in the words of Anderson; the ordinary Australian had yet to believe these new Liberals were 'dinkum'. Yet at the same time there was correctly perceived to be a rising tide of anxiety about the directions of post-war Australia, and those who had rallied to the call of the new party displayed a 'revived enthusiasm' (Hancock 2000: 88) in setting out to defeat socialism. But just how to harness this need to popular sentiment remained problematic. It was a speech a few months after Anderson's by R. G. Casey ${ }^{4}$ that clearly spelled out for the first time just what it was that the Liberals lacked and what they must do. The address, to a Liberal Party Victorian State Council meeting, took the form of a rather blunt mea culpa, and spelled out what the Liberals had to do to build on their creation of a mass party. Electoral success would follow only when that foundation was augmented by mass appeal; in other words, the Liberal Party had to reach out beyond the confines of its own membership if it was to become a real political force; it had to be more engaged in the lives of the ordinary people.

I am one of the many who believe that we Liberals should identify ourselves to the greatest extent possible with the lives of the people. In the past (I am talking of before the war) on our side in politics we tended to live in an ivory tower. We did not have anything like as much contact with the everyday lives of the ordinary average men and women. I am hoping very much that from now on we will increase our efforts to unify ourselves all over Australia with the lives of the ordinary Australian men and women, particularly with those on lower incomes (Casey 1947). 
Quite pointedly, Casey, then Federal President of the Liberal Party, was delivering a call to action, a call to go out and become one with 'the ordinary Australian men and women', a call for the Liberal Party to make itself relevant to the everyday concerns of the people and to connect with them; above all, it was a call to talk to the Australian people in a more colloquial voice, a voice that was unambiguously Australian, a voice that spoke to all Australians, irrespective of creed or economic or social status.

\section{Getting 'dinkum': enter Bolte and Askin}

The Liberals in Victoria pre-Bolte and in New South Wales pre-Askin were poor relations indeed to the successful political machine that Menzies and others had built and with which the Coalition surged to office in 1949. In Victoria, the Liberals had suffered two damaging splits in seven years, and its leadership was inept at best. Tom Hollway, the only Liberal Premier before Bolte, was unable to control tensions within his own party (indeed, he was the cause of many of them), and in any case preferred to govern in consultation with a small circle of advisers outside the party. When Hollway was deposed, the Liberals elected a brooding and intense former prisoner-of-war, Les Norman, who lost his seat without ever making an impact, and then turned to a party veteran, Trevor Oldham, who soon after died in an air crash. When Bolte became leader of a mere cricket team of Liberals in 1953, confronting not only a majority Labor Government and a hostile Country Party, but also a clutch of dissident Liberals under Hollway known first as the Electoral Reform Group and later the Victorian Liberal Party, he faced a very uncertain future. But owing to internecine warfare inside the ALP, he was Premier within two years and held the job, unchallenged, for 17 years. He displayed not only political skills of a high order that maximised his undoubted good fortune, but he brought to the office man-management skills that helped transform a motley rabble into a disciplined government that gave, and received, loyalty. An early supporter of Bolte, even before he became leader, was the party president and a member of the Melbourne business establishment, J. M. Anderson (no relation to W. H. Anderson) who arranged for Bolte to make regular broadcasts on station 3XY, then owned by the Liberal Party.

We picked on Henry because he showed he had flair. He was shrewd but not cunning. That's what appealed to us. He was a man on the land, in direct contrast to the people we'd been used to. He was always ready to sit down and talk things out (Blazey 1990: 58).

In New South Wales, the non-Labor parties had been in opposition for 18 years by the time Askin was elected to the Liberal leadership after the 1959 election defeat. To many, both in the party and outside it, the Liberal Party in that state was doomed to be a permanent opposition. Four leaders had come and three had gone in as many years: Vernon Treatt, a Rhodes Scholar, barrister and decorated 
war hero; Murray Robson, a socialite solicitor and former lieutenant-colonel; and Pat Morton, a successful businessman from a political family. Despite a professional party organisation, at the parliamentary level the Liberals were still in many ways a pre-modern party with most members engaged in business and two even ran industry organisations. Askin, a former bank employee and army sergeant, changed all that. He declared himself when he became leader 'a professional politician'. It was a line drawn in the sand that signified a real break with the past and an entirely new approach. The era of Liberals in New South Wales being part-time politicians was over. John Carrick, who served as General Secretary of the Liberal Party 1948-1971 saw Askin as a political pragmatist whose appeal opened up new avenues to potential voters.

I would give Askin full marks for his policies. He picked the policies out of the grab bag the party had thrown up over a period. He looked at the small shopkeeper kind of show; he looked at the little man who was being picked on with regulations and so on. So he was using things that had irritated people from the end of the war, and he used it and got what he deserved. With Askin we had a person whom we thought would be acceptable to what we called the little voter. That was our campaign theme. It was quite authentic; he was very naturally inclined that way (Carrick 2002).

Interestingly, both Bolte and Askin served as non-commissioned officers in World War II whereas the majority of those who served under them had been officers.

\section{Table 1. The Bolte Cabinet (1955) and Military Service}

\begin{tabular}{l|l|l}
\hline Name & Military Service & Officer or Ranks \\
\hline Henry Bolte & Yes & Ranks \\
\hline Arthur Rylah & Yes & Officer \\
\hline Arthur Warner & Yes & Officer \\
\hline Gilbert Chandler & No & \\
\hline William Leggatt & Yes & Officer \\
\hline Thomas Maltby & Yes & Officer \\
\hline Ewen Cameron & Yes & Officer \\
\hline Wilfred Mibus & No & \\
\hline Robert Whately & No & \\
\hline John Bloomfield & Yes & Officer \\
\hline Horace Petty & Yes & Officer \\
\hline Keith Turnbull & No & \\
\hline George Reid & Yes & Officer \\
\hline Gordon McArthur & Yes & Officer \\
\hline
\end{tabular}


Table 2. The Askin Cabinet (1965) and Military Service

\begin{tabular}{l|l|l}
\hline Name & Military Service & Officer or Ranks \\
\hline Robin Askin & Yes & Ranks \\
\hline Charles Cutler & Yes & Officer \\
\hline Eric Willis & Yes & Ranks \\
\hline Arthur Bridges & No & \\
\hline William Chaffey & Yes & Officer \\
\hline Kenneth McCaw & No & \\
\hline Philip Morton & No & \\
\hline Davis Hughes & Yes & Officer \\
\hline Milton Morris & No & \\
\hline John Fuller & No & \\
\hline Thomas Lewis & Yes & Officer \\
\hline Jack Beale & No & \\
\hline Stanley Stephens & Yes & Ranks \\
\hline Harry Jago & Yes & Officer \\
\hline Wallace Fife & No & \\
\hline John Maddison & Yes & Officer \\
\hline
\end{tabular}

There was a knockabout quality to both men who had been active in sport and social groups for many years, and their military experience was also relatively rough-hewn in comparison to their commissioned brothers. It is argued here that it was precisely these qualities that enabled both Bolte and Askin to feel at ease among people; this worked at both a parliamentary level, where keen people management was required and also at the electorate level where a sense of purpose and reliability needed to be communicated. Their public images of beer drinkers who liked a bet on the horses and went to the football resonated with the electorate in a way that no Liberals had managed before and few have since. Two other successful modern Liberal leaders, David Brand in Western Australia and Tom Playford in South Australia, also came from socially modest NCO backgrounds; both men attributed their political success, in part, to their military experiences serving in the ranks.

After an uncertain start, the Liberals, especially at state level, set about demonstrating their bona fides to an electorate that had, quite justifiably, developed a lingering scepticism about the capabilities and genuineness of the non-Labor cause, especially as it was represented by the effete United Australia Party. Clearly, a new message had to be devised along with new ways of communicating it, and that involved a new type of leader and style of leadership.

\section{Conclusion: dinkum vs. gravitas in Liberal leadership styles}

There are many similarities between Bolte and Askin, the greatest of which is that each was an outsider in terms of the accepted norms of Liberal Party leadership. ${ }^{5}$ Neither was from a moneyed background (Askin's was in fact quite poor). Each inherited a party that was deeply divided and presided over a unifying process that was characterised by loyalty. Neither was ever challenged 
for the duration of their leadership. Each chose the timing of his departure from politics. Why were these apparent outsiders so accepted, so unchallenged, and so successful?

This chapter argues that their differentiation from the norms of their parties was very much a source of their strength and appeal as leaders. They broke the perceived class nexus that had divided parties and their background as NCOs, rather than officers, in the aftermath of World War II, laid an emphasis on teamwork that had been noticeably lacking in previous non-Labor parties. They led rather than commanded. Their demeanour was that of the ordinary person; their habits those of the average Australian. Their immediate appeal cut across fault lines that had previously been defined by an unspoken class affiliation; the language they spoke and the symbols they represented were of the public bar, not the saloon bar.

Each in his own way also represented a type that was in keeping with perceptions of their respective states, ${ }^{6}$ especially the capital cities. Bolte, who had religious beliefs (and once even contemplated a career as a preacher) was wary of issues deemed to be in the moral domain, as much from personal conviction as from strategic considerations in keeping the DLP firmly on side. Victoria's laws on censorship, for example, were stringent: Sunday newspapers were forbidden, cinema hours on the sabbath, when they were at last allowed to open, were restricted, and hotels closed at 6:00 pm until 1966.

Askin, very much a Sydney man, professed no religious conviction. He was, like his city, free and easy-going in attitude and politics. His own attitude to authority had a certain cavalier streak. He was, for example, a keen SP (starting price) punter when SP betting was illegal but nonetheless prevalent.

Looming large over any discussion of the history of the Liberal Party, and especially of the issue of leadership, is the glowering shadow of Robert Menzies. Menzies, it is true, came from a position in which he was regarded with scepticism in the eyes of the electorate, to a position of dominance, just as the Liberal Party itself did. Yet did he prove himself to be, as the Liberal founders hoped, dinkum?

In a broad sense he did, though not in the same way that ensuing leaders in the field of state politics did, which suggests significant differences in the respective domains: one overarching, so to speak, the other almost personal. Menzies displayed a gravitas that became a trademark. Men such as Bolte and Askin exhibited a folksy earthiness that was almost the opposite, yet dinkum in the strongest colloquial sense. They were, however, no less authoritative as leaders. Indeed, Menzies himself grappled with these distinctions when seeking to explain the appeal of Henry Bolte, noting that Australian people were not interested in 'philosophical disquisitions' by their political leaders, and displayed an 'instinctive resistance' to being talked down to. He continued: 
Whenever Henry Bolte came out with an impromptu observation on some matter presented to him by a Press report, I confess that I used to worry a little. But I was wrong. By the time his observations had been reported in the Press, most people were saying: 'Good old Henry, he speaks what's on his mind'. Now that, properly considered, is a wonderful democratic attribute. It made him familiar to all Victorians and, indeed, to many thousands of people in other States. He was, and is, a man's man (Menzies 1973: viii).

In popular parlance, a man's man was to be 'a good bloke'. This was someone who rubbed shoulders with all comers, and was devoid of the airs and graces of those who considered themselves superior. Menzies, who remains sui generis, was never in any doubt as to his own superiority. The leavening experience of war service, and the rough and levelling camaraderie that it generates, were never part of his make up. For all his appeal, Menzies lacked the colloquial appeal of his more plainspoken state colleagues. This is apparent in his openly paraded attachment to England - 'the locus of Menzies' ideals, the ultimate source of value in his political world' (Brett 1997: 71). It was also apparent in his 'well-modulated voice with its full vowels and clearly enunciated consonants, the sort of voice which conveyed education, confidence and respect for England' (Brett 1992: 15). In the Australia of the time, it denoted a certain class and station in life; it was not the voice of the public bar or the outer at a sporting arena.

To what extent any minister could oppose Menzies is problematic. One junior minister observed in a diary entry: 'He led by dominating, not by team work' (Howson in Aitkin 1984: 203). Menzies' own muted mea culpa on his first unsuccessful prime ministership, in which he frankly admitted that his 'knowledge of people, and how to get along with them and persuade them, lagged behind' was only ever partly addressed.

I was still in that state of mind in which to be logical is to be right, and to be right is its own justification. I had yet to acquire the common touch, to learn that human beings are delightfully illogical but mostly honest, and to realise that all-black and all-white are not the only hues in the spectrum (Menzies 1969: 57).

These criticisms would not be made of the worldly state leaders who would come after Menzies, the men who would lead rather than just command. 


\section{References}

'Triumph or Disaster?' IPA Review, Jan-Feb 1949, 3:1, pp. 13-4.

Anderson, W. H., 1947, Address to Eighth State Council of Victorian Division, 12 August, p. 3. University of Melbourne Archives, Liberal Party records $1 / 1 / 2$.

Berry, J. W., 1969, 'The Stereotypes of Australian States', Australian Journal of Psychology, 21:3, pp. 227-33.

Blazey, Peter, 1990, Bolte: A Political Biography, Port Melbourne: Mandarin, p. 58.

Brett, Judith, 1997, 'Robert Menzies and England', in Brett (ed.) Political Lives, St Leonards: Allen \& Unwin, p. 71.

Brett, Judith, 1992, Robert Menzies' Forgotten People, Chippendale: Sun Australia, p. 15.

Carrick, John, 2002, Personal interview conducted by author, 24 May.

Fairfax, Warwick, 1943, Men, Parties and Politics, Sydney: John Fairfax and Sons.

Galligan, Brian, 1986, 'Introduction', in B. Galligan (ed.), Australian State Politics, Melbourne: Longman, p. x.

Hancock, Ian, 2000, National and Permanent? The Federal Organisation of the Liberal Party of Australia 1944-1965, Carlton South: Melbourne University Press, p. 88.

Hasluck, Paul, 1970, The Government and the People 1942-1945, Australian War Memorial, Canberra, p. 625.

Horne, Donald, 2000, Into the Open, Sydney: Harper Collins, p. 96.

Howson, Peter, 1984, in Don Aitkin, (ed.), The Howson Diaries. The Life of Politics, Ringwood: Viking, 1984, p. 203.

Lampe, F. E., 1943, 'Thoughts at Random on the Recent Election,' 30 August. Noel Butlin Archive Centre (ANU), IPA, N136/74, p. 1.

Lonie, John, 1978, 'From Liberal to Liberal: the Emergence of the Liberal Party and Australian Capitalism, 1900-45', in Graeme Duncan (ed.), Critical Essays in Australian Politics, Port Melbourne: Edward Arnold, p. 69.

Menzies, Robert, 1969, Afternoon Light: Some Memories of Men and Events, Ringwood: Penguin, p. 293.

Menzies, Robert, 1973, foreword in Barry Muir, Bolte From Bamganie, Melbourne: Hill of Content, 1973, p. viii. 
Ritchie, T. M., 1945, Speech to Darlinghurst branch, Liberal Party, 4 July. Ritchie papers, NLA, MS 2555, Box 1, speeches.

Sydney Morning Herald, 15 July 1943a.

Sydney Morning Herald, 2 Sept 1943c.

Sydney Morning Herald, 3 Sept 1943b.

UMA, Liberal Party records, 1/1/2.

\section{ENDNOTES}

1 Frederic Ernest Lampe (1992-1972), retailer and businessman.

2 Thomas Malcolm Ritchie (1894-1971), businessman and Liberal Party founder.

3 William Hewson Anderson (1897- 1968), chief accountant Shell Co. of Australia 1935-50. President of the Victorian Division of the Liberal Party 1945-48 and Federal President 1951-56. His role in the formation of the Liberal Party was a significant one as it was in the first decade of its existence. Anderson was among the conservative critics of the UAP and had formed with others the Services and Citizens' Party, one of the splinter parties that later became part of the new Liberal Party.

4 Richard Gardiner Casey (1890-1976), MHR Corio 1931-40, La Trobe 1949-60; Minister for Works and Housing 1949-50, Minister for National Development 1950-56, Minister for External Affairs 1951-60, Minister in charge of CSIRO 1950-60. Created a life peer as Baron Casey of Berwick. Governor-General of Australia 1965-69.

5 Even on the verge of Askin's succession to the Premiership, the media proprietor Sir Frank Packer, according to Donald Horne, was concerned that the Liberal Party was not giving their own man 'a fair go'; there was concern that 'he was only a sergeant in the war ... not enough rank' (Horne 2000: 96).

6 For a discussion of these perceptions see Berry (1969). 